\title{
Frequency, type and clinical importance of medication history errors at admission to hospital: a systematic review
}

\author{
Vincent C. Tam, Sandra R. Knowles, Patricia L. Cornish, Nowell Fine, Romina Marchesano, \\ Edward E. Etchells
}

Abstract

Background: Over a quarter of hospital prescribing errors are attributable to incomplete medication histories being obtained at the time of admission. We undertook a systematic review of studies describing the frequency, type and clinical importance of medication history errors at hospital admission.

Methods: We searched MEDLINE, EMBASE and CINAHL for articles published from 1966 through April 2005 and bibliographies of papers subsequently retrieved from the search. We reviewed all published studies with quantitative results that compared prescription medication histories obtained by physicians at the time of hospital admission with comprehensive medication histories. Three reviewers independently abstracted data on methodologic features and results.

Results: We identified 22 studies involving a total of 3755 patients (range 33-1053, median 104). Errors in prescription medication histories occurred in up to $67 \%$ of cases: $10 \%-$ $61 \%$ had at least 1 omission error (deletion of a drug used before admission), and $13 \%-22 \%$ had at least 1 commission error (addition of a drug not used before admission); $60 \%-67 \%$ had at least 1 omission or commission error. Only 5 studies ( $n=545$ patients) explicitly distinguished between unintentional discrepancies and intentional therapeutic changes through discussions with ordering physicians. These studies found that $27 \%-54 \%$ of patients had at least 1 medication history error and that $19 \%-75 \%$ of the discrepancies were unintentional. In 6 of the studies ( $n=588$ patients), the investigators estimated that $11 \%-59 \%$ of the medication history errors were clinically important.

Interpretation: Medication history errors at the time of hospital admission are common and potentially clinically important. Improved physician training, accessible community pharmacy databases and closer teamwork between patients, physicians and pharmacists could reduce the frequency of these errors.

CMAJ 2005;173(5):510-5

$\mathrm{U}$ to $27 \%$ of all hospital prescribing errors can be attributed to incomplete medication histories at the time of admission. ${ }^{1}$ There is growing interest in the identification and rectification of medication errors at the time of admission, transfer and discharge ("medication reconciliation"). Medication reconciliation is a 2005 Canadian Council on Health Services Accreditation re- quirement and a 2005 Hospitals' National Patient Safety Goal established by the US Joint Commission on Accreditation of Healthcare Organizations., ${ }^{2,3}$

Accurate medication histories at the time of hospital admission are an important element of medication safety. First, they may uncover reasons for a patient's illness, such as adverse drug events or nonadherence to drug therapy. Second, medication history errors may result in interrupted or inappropriate drug therapy during and following the hospital stay. Third, computerized physician order entry (CPOE) systems could fail to detect these errors. For example, CPOE systems would not be capable of detecting unintentional omissions of medications taken before admission without a link to community pharmacy databases.

Given the potential importance of and growing health policy focus on medication history errors at the time of hospital admission and the lack of previously published comprehensive reviews of this topic, we conducted a systematic review of the literature describing the frequency, type and clinical importance of such errors.

\section{Methods}

A structured search strategy was developed using relevant articles on file. We searched MEDLINE for English-language articles published from 1966 through April 2005 using the following $\mathrm{MeSH}$ (medical subject heading) terms: "medication history taking," "medication errors," "physicians," "pharmacists," "prescription medications," "pharmaceutical preparations," "hospital medication systems," "hospital pharmacy services" and "medical records." The search strategy was deliberately broad to ensure inclusion of the maximum number of relevant articles (details of the search strategy appear in on online appendix, available at www .cmaj.ca/cgi/content/full/173/5/510/DC1). All bibliographies of papers identified in the search were screened for additional articles, and this was done subsequently for all papers retrieved. We searched the EMBASE and CINAHL databases using a similar search strategy.

Two of us (V.C.T. and R.M.) identified relevant articles for retrieval by screening the titles, abstracts and subject headings of the MEDLINE citations for the following inclusion criteria: primary research article; comparison of physician-acquired medication histories (chart notes, admission orders or medication administration record) with comprehensive medication histories; adult inpatient population; and sample size of at least 30 patients. Full- 
text versions of the identified papers were retrieved and screened again by the 2 independent readers for the inclusion criteria.

All included articles were independently reviewed by 3 of us (V.C.T., N.F. and E.E.E.) for methodological features and results. Any discrepancies were resolved through discussion.

The reviewed studies were analyzed on the basis of their explicit descriptions of prospective or retrospective design, use of consecutively enrolled patients and adequate blinding. Quality grades were assigned as follows: grade A studies had prospective enrolment of consecutive patients and a sample size of at least 100 patients; grade B studies had prospective enrolment of consecutive patients and a sample size of less than 100; grade C studies included all other designs.

We sought data on prescription medication histories obtained by physicians at the time of hospital admission. Such data could include physician admission notes, admission medication orders or medication administration records. We also recorded data on the main comparative measure, which was usually a comprehensive medication history completed by a pharmacist. The comparative measure could have included a patient interview, a review of the physician's admission notes or admission medication orders, a review of medication lists, and contact with community pharmacists and physicians. An error in a prescription medication history was defined as a discrepancy between the medication history obtained by the physician and the comprehensive medication history. We also recorded discrepancies for nonprescription medications, allergy history and prior adverse drug reactions, when reported. Discrepancies between physician-acquired medication histories and comprehensive medication histories are not necessarily errors. Some "discrepancies" may be intentional therapeutic adjustments of the patient's usual medications by the treating physician. Physicians may choose to discontinue a specific medication, or adjust its dose, without documenting a reason in the chart. Therefore, we sought evidence from the studies of discussions with ordering physicians to distinguish intentional from unintentional discrepancies.

Certain medication history errors have more potential for harm than others. A reduction in laxative dose may have less consequence than the abrupt discontinuation of a $\beta$-blocker, for example. Therefore, we sought data from each study regarding the clinical importance of the errors.

We calculated the proportion of patients with 1 or more prescription medication history errors and the mean number of medication discrepancies per patient from each study whenever possible. The study methods and results were heterogeneous, and therefore we made no attempt to combine results for a meta-analysis.

\section{Results}

The screening and selection process of relevant studies is summarized in Fig. 1. No additional relevant papers were found in the EMBASE and CINAHL searches.

We included 22 studies in our review. These studies enrolled a total of 3755 patients (range 33-1053, median 104). The methodological features of the studies are summarized in Table 1 (a more detailed version of the table is available online at www.cmaj.ca/cgi/content/full/173/5/510 /DC2). Five studies had a prospective design and enrolled consecutive patients. ${ }^{4,5,10,19,23}$ Seven studies were retrospec- tive. $6,9,11,14,17,18,24$ A total of 8 studies enrolled consecutive patients. ${ }^{47,10,19,21,23}$ Four of the studies had a blinded design: the pharmacist investigators obtained their comprehensive medication histories independent of the physicians' medication histories. ${ }^{4,8,9,25}$ Ten of the studies were conducted on medical wards, ${ }^{5,9,11,12,15,17,1,2,21,23,25} 4$ on mixed medical and surgical wards, ${ }^{8,13,16,22} 2$ on surgical wards, ${ }^{4,6} 1$ in the emergency department ${ }^{7}$ and 1 in a psychiatric hospital ${ }^{14} 4$ studies did not explicitly state the hospital ward setting. ${ }^{10,18,20,24}$ Twelve of the studies described explicit inclusion and exclusion criteria; the most common inclusion criteria were that the patient was taking at least 1 prescription medication and that he or she was able to provide a medication history.

\section{Frequency of errors}

Studies reported that $10 \%-67 \%$ of patients had at least 1 prescription medication history error (Table 1). When nonprescription drugs were included, the frequency of errors was $27 \%-83 \%$. When information regarding drug allergies or prior adverse drug reactions was added the frequency was $34 \%-95 \%$ of patients with at least 1 error.

\section{Types of errors}

There was considerable variation in the definition of medication history errors at admission. Some studies included only omission errors (deletion of a drug used before admission), whereas others included frequency and dose errors as well as commission errors (addition of a drug not

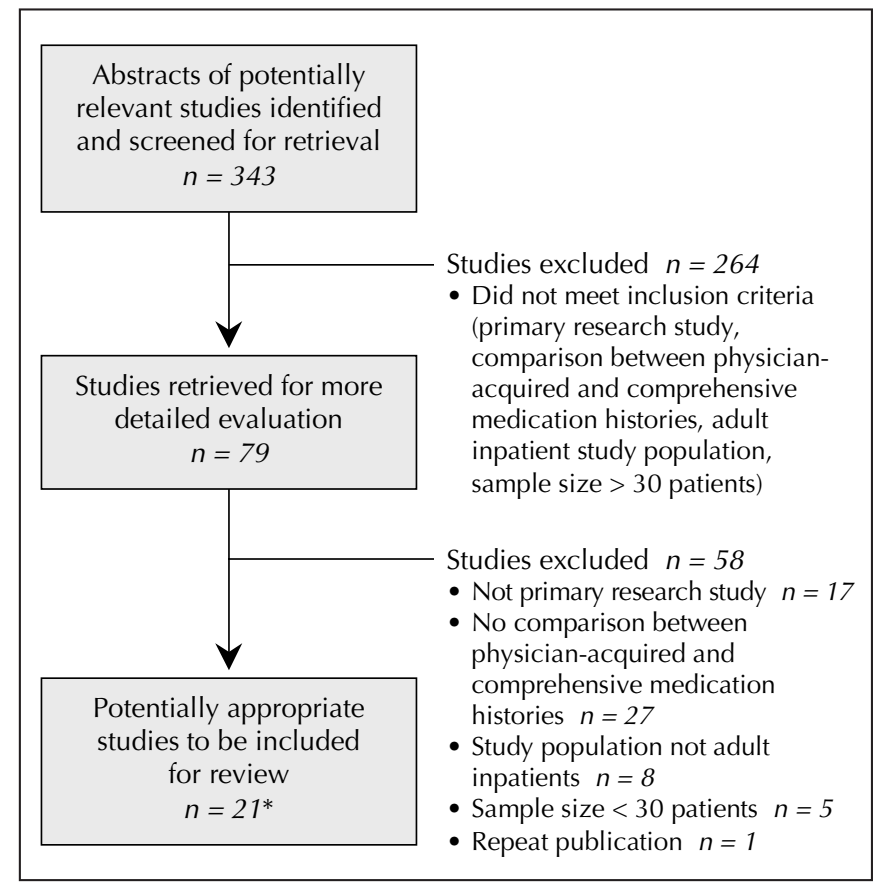

Fig. 1: Method of study selection. *An additional study not indexed in MEDLINE was identified through review of relevant subspecialty journals. 
used before admission). Examples of these error types are shown in Table 2.

Studies reported that $10 \%-61 \%$ of patients had at least 1 omission error and that $13 \%-22 \%$ had at least 1 commission error; $60 \%-67 \%$ had at least 1 omission or commission error. ${ }^{6,10,14,19}$ Three studies that evaluated a broad range of error types found that omission errors accounted for $42 \%-59 \%$ of all prescription medication history errors, whereas errors in dose or frequency accounted for $30 \%-42 \% .{ }^{5,15,22}$

Five studies explicitly distinguished between unintentional discrepancies (medication history errors) and intentional therapeutic changes. ${ }^{5,9,12,15,16}$ Four of these studies reported the

Table 1: Summary of studies of medication history errors included in review (abridged*)

\begin{tabular}{|c|c|c|c|c|c|c|}
\hline \multirow[b]{2}{*}{ Study } & \multirow[b]{2}{*}{$\begin{array}{l}\text { Sample } \\
\text { size }\end{array}$} & \multirow[b]{2}{*}{$\begin{array}{l}\text { Quality } \\
\text { grade }\end{array}$} & \multirow[b]{2}{*}{$\begin{array}{c}\text { Type of medication } \\
\text { history error } \neq\end{array}$} & \multicolumn{2}{|c|}{ Prescription medications } & \multirow[b]{2}{*}{ Other main results } \\
\hline & & & & $\begin{array}{l}\% \text { of patients } \\
\text { with } \geq 1 \text { error }\end{array}$ & $\begin{array}{l}\text { Mean no. of } \\
\text { errors per patient }\end{array}$ & \\
\hline $\begin{array}{l}\text { Akwagyriam } \\
\text { et } \mathrm{al}^{7}\end{array}$ & 33 & B & $\begin{array}{l}\text { - Omission } \\
\text { - Incorrect dose }\end{array}$ & - & 1.5 & $\begin{array}{l}73 \% \text { of patients had } \geq 1 \text { error (mean } \\
2.3 \text { errors per patient) when both } \\
\text { prescription and nonprescription } \\
\text { medications were included in medication } \\
\text { history }\end{array}$ \\
\hline Badowski et $\mathrm{al}^{8}$ & 80 & C & $\begin{array}{l}\text { - Incorrect drug name } \\
\text { - Incorrect strength } \\
\text { - Incorrect dose }\end{array}$ & 57 & - & $\begin{array}{l}95 \% \text { of patients had } \geq 1 \text { error when } \\
\text { prescription medications, nonprescription } \\
\text { medications, drug allergies and } \\
\text { compliance were included in medication } \\
\text { history }\end{array}$ \\
\hline Barger et $\mathrm{al}^{9}$ & 50 & C & - Omission & - & - & $\begin{array}{l}\text { Pharmacist-acquired medication histories } \\
\text { yielded twice as many prescription } \\
\text { medications as physician-acquired } \\
\text { medication histories }\end{array}$ \\
\hline Beers et $\mathrm{al}^{10}$ & 122 & A & $\begin{array}{l}\text { - Omission } \\
\text { - Commission }\end{array}$ & 60 & - & $\begin{array}{l}52 \% \text { of patients had prescription errors if } \\
\text { only omission errors were included; } 83 \% \\
\text { of patients had } \geq 1 \text { error when both } \\
\text { prescription and nonprescription } \\
\text { medications were included in medication } \\
\text { history }\end{array}$ \\
\hline Brookes $^{11}$ & 109 & C & $\begin{array}{l}\text { - Omission } \\
\text { - Commission } \\
\text { - Incorrect strength } \\
\text { - Incorrect dose }\end{array}$ & - & - & $\begin{array}{l}61 \% \text { of patients had } \geq 1 \text { error when both } \\
\text { prescription and nonprescription medications } \\
\text { were included in medication history }\end{array}$ \\
\hline Cohen et $\mathrm{al}^{12}$ & 60 & C & - Omission & - & - & $\begin{array}{l}48 \% \text { of patients had } \geq 1 \text { error when both } \\
\text { prescription and nonprescription medications } \\
\text { were included in medication history }\end{array}$ \\
\hline Cornish et $\mathrm{al}^{5}$ & 151 & A & $\begin{array}{l}\text { - Omission } \\
\text { - Commission } \\
\text { - Incorrect dose } \\
\text { - Incorrect frequency }\end{array}$ & 54 & 0.9 & - \\
\hline $\begin{array}{l}\text { Covington } \\
\text { et } \mathrm{al}^{13}\end{array}$ & 58 & C & - Omission & - & 2.7 & - \\
\hline Dobbs $^{14}$ & 50 & C & - Omission & 24 & 0.4 & $\begin{array}{l}48 \% \text { of patients had } \geq 1 \text { error when } \\
\text { prescription medications, nonprescription } \\
\text { medications, adverse drug events and } \\
\text { alcohol use were included in medication } \\
\text { history }\end{array}$ \\
\hline Dodds $^{4}$ & 146 & A & - Omission & - & - & $\begin{array}{l}\text { Mean } 0.4 \text { errors per patient when } \\
\text { prescription and nonprescription medications } \\
\text { were included in medication history }\end{array}$ \\
\hline Drewett $^{15}$ & 80 & C & $\begin{array}{l}\text { - Omission } \\
\text { - Incorrect dose } \\
\text { - Incorrect frequency }\end{array}$ & - & - & $\begin{array}{l}34 \% \text { of patients had } \geq 1 \text { error (mean } \\
0.3 \text { per patient) when prescription } \\
\text { medications, nonprescription medications } \\
\text { and drug allergies were included in } \\
\text { medication history }\end{array}$ \\
\hline
\end{tabular}


proportion of patients who had at least 1 medication history error (range $27 \%-54 \%$ ); ${ }^{5,12,15,16}$ the fifth study showed that the comprehensive medication history yielded twice as many prescription medications as the physician-acquired medication history. ${ }^{9}$ Three of the 5 studies reported the proportion of discrepancies that were unintentional (range 19\%-75\%). $.9,16$
One of the 5 studies examined prescription medications only, ${ }^{5}$ reporting that $54 \%$ of the patients had at least 1 medication history error. In the 3 studies that examined discrepancies in prescription and nonprescription medication histories as well as other aspects of the medication history, $27 \%-48 \%$ of the patients had at least 1 medication history error. ${ }^{12,15,16}$

\section{Table 1 continued}

\begin{tabular}{|c|c|c|c|c|c|c|}
\hline \multirow[b]{2}{*}{ Study } & \multirow[b]{2}{*}{$\begin{array}{l}\text { Sample } \\
\text { size }\end{array}$} & \multirow[b]{2}{*}{$\begin{array}{l}\text { Quality } \\
\text { grade } †\end{array}$} & \multirow[b]{2}{*}{$\begin{array}{l}\text { Type of medication } \\
\text { history error } \neq\end{array}$} & \multicolumn{2}{|c|}{ Prescription medications } & \multirow[b]{2}{*}{ Other main results } \\
\hline & & & & $\begin{array}{l}\% \text { of patients } \\
\text { with } \geq 1 \text { error }\end{array}$ & $\begin{array}{l}\text { Mean no. of } \\
\text { errors per patient }\end{array}$ & \\
\hline Gleason et $\mathrm{al}^{16}$ & 204 & $\mathrm{C}$ & $\begin{array}{l}\text { - Omission } \\
\text { - Commission } \\
\text { - Incorrect dose } \\
\text { - Incorrect frequency }\end{array}$ & - & - & $\begin{array}{l}\text { Up to } 27 \% \text { of patients had } \geq 1 \text { unintended } \\
\text { discrepancy between admission orders and } \\
\text { comprehensive medication history (mean } \\
0.34 \text { discrepancies per patient) when both } \\
\text { prescription and nonprescription medications } \\
\text { were included in medication history }\end{array}$ \\
\hline Gurwich $^{17}$ & 86 & $\mathrm{C}$ & - Omission & - & 3.2 & - \\
\hline Hocking et $\mathrm{al}^{6}$ & 1053 & $\mathrm{C}$ & - Omission & 10 & - & - \\
\hline La Verde ${ }^{18}$ & 205 & C & $\begin{array}{l}\text { - Omission } \\
\text { - Incorrect dose }\end{array}$ & - & - & $\begin{array}{l}\text { Pharmacist-acquired medication histories } \\
\text { yielded } 87 \% \text { more information than } \\
\text { physician-acquired medication histories; } \\
\text { pharmacists noted more prescription } \\
\text { medications than physicians }\end{array}$ \\
\hline Lau et $\mathrm{al}^{19}$ & 304 & A & $\begin{array}{l}\text { - Omission } \\
\text { - Commission }\end{array}$ & 67 & 1.5 & $\begin{array}{l}61 \% \text { of patients had prescription errors when } \\
\text { only omission errors were included }\end{array}$ \\
\hline Massey $^{20}$ & 60 & $\mathrm{C}$ & $\begin{array}{l}\text { - Omission } \\
\text { - Incorrect strength } \\
\text { - Incorrect dose }\end{array}$ & - & - & $\begin{array}{l}42 \% \text { of patients had } \geq 1 \text { error when } \\
\text { prescription medications, nonprescription } \\
\text { medications, drug allergies and adverse drug } \\
\text { reactions were included in medication } \\
\text { history }\end{array}$ \\
\hline $\begin{array}{l}\text { Montpetit } \\
\text { et } \mathrm{al}^{21}\end{array}$ & 43 & B & $\begin{array}{l}\text { - Omission } \\
\text { - Incorrect frequency }\end{array}$ & - & - & $\begin{array}{l}\text { Pharmacists performing structured interviews } \\
\text { with a patient-completed form obtained } \\
91 \%-99 \% \text { of the total prescription } \\
\text { medication information, as compared with } \\
68 \%-84 \% \text { of information acquired by } \\
\text { physicians and nurses in chart notes }\end{array}$ \\
\hline Nicholls et al ${ }^{22}$ & 328 & $\mathrm{C}$ & $\begin{array}{l}\text { - Omission } \\
\text { - Commission } \\
\text { - Incorrect dose } \\
\text { - Incorrect frequency }\end{array}$ & - & 0.3 & - \\
\hline Truitt et $\mathrm{al}^{23}$ & 186 & A & $\begin{array}{l}\text { - Omission } \\
\text { - Commission }\end{array}$ & - & 0.9 & $\begin{array}{l}75 \% \text { of patients had } \geq 1 \text { error (mean } 2.24 \text { per } \\
\text { patient) when both prescription and } \\
\text { nonprescription medications were included } \\
\text { in medication history }\end{array}$ \\
\hline Walche et $\mathrm{al}^{24}$ & 247 & $\mathrm{C}$ & - Omission & - & - & $\begin{array}{l}\text { Mean } 1.9 \text { prescription medications per } \\
\text { patient identified in pharmacist-acquired } \\
\text { medication histories, as compared with mean } \\
1.3 \text { per patient in physician-acquired } \\
\text { medication histories }\end{array}$ \\
\hline Wilson et $\mathrm{al}^{25}$ & 100 & C & $\begin{array}{l}\text { - Omission } \\
\text { - Commission }\end{array}$ & - & 0.5 & $\begin{array}{l}\text { Mean } 1.2 \text { errors per patient when } \\
\text { prescription and nonprescription medications } \\
\text { were included in medication history }\end{array}$ \\
\hline
\end{tabular}

Note: "error" = discrepancy between physician-acquired medication history and comprehensive medication history.

*Details about the sources of medication histories (physician and comprehensive) appear in an expanded online version of this table (available at www.cmaj.ca/cgi/content/full/173/5/510/DC2).

†Grade A studies had prospective enrolment of consecutive patients with a sample size of at least 100; grade B studies had prospective enrolment of consecutive patients with a sample size of less than 100; grade $\mathrm{C}$ studies included all other designs (e.g., retrospective and nonconsecutive patient studies).

$\ddagger$ Omission error = deletion of a drug used before admission, commission error = addition of a drug not used before admission. See Table 2 for examples of the types of medication errors. 


\section{Sources of medication histories}

There was some heterogeneity in the methods used to obtain the physician-acquired medication histories. Most studies used the physicians' admission chart notes. Two used admission medication orders., ${ }^{5,16}$ Two other studies used medication administration records. ${ }^{12,15}$

There was significant heterogeneity in the methods used to obtain the comprehensive medication histories. One retrospective study relied solely on chart notes written by pharmacists. ${ }^{17}$ Other studies used a pharmacist's interview alone, but the content and method of the interview was often not explicitly stated. ${ }^{4,7-9,13,20,24,25}$ Several other studies used explicit structured interview methods to obtain drug information. ${ }^{6,21,23} \mathrm{Fi}-$ nally, some obtained the comprehensive medication history from multiple sources, which may have included interviews, physician chart notes, standardized forms, family physician records, inspection of medication vials, and review of community pharmacy records and hospital records. ${ }^{5,11,12,15,16,18,19,21}$

\section{Clinical importance of errors}

Six studies described the clinical importance of medication history errors. ${ }^{5,7,8,12,16,20}$ Clinical importance was usually determined by consensus among a panel of experts that included physicians or pharmacists or both. Only 1 of these studies examined prescription medication history errors in isolation: it found that $39 \%$ of the errors had the potential to cause moderate or severe patient discomfort or deterioration in the patient's condition. ${ }^{5}$

Three studies included both prescription and nonprescription medication history errors. One showed that $41 \%$ of the errors were clinically important. ${ }^{7}$ Another showed that $3 \%$ of the patients had medications omitted from their

\section{Table 2: Examples of medication history errors*}

\begin{tabular}{|c|c|}
\hline Type of error & Example \\
\hline Omission & $\begin{array}{l}\text { A patient admitted because of recurrent pre- } \\
\text { syncope was taking digoxin } 0.125 \text { mg daily before } \\
\text { admission to hospital. The digoxin therapy was } \\
\text { not recorded in the medication history }\end{array}$ \\
\hline Commission & $\begin{array}{l}\text { A stroke patient with aphasia was admitted to } \\
\text { hospital. The family provided the medication vials } \\
\text { from home, and these medications were ordered, } \\
\text { including propafenone. After recovering from his } \\
\text { aphasia, the patient stated that his cardiologist had } \\
\text { advised him to stop the propafenone therapy } \\
\text { several months ago }\end{array}$ \\
\hline $\begin{array}{l}\text { Incorrect } \\
\text { frequency }\end{array}$ & $\begin{array}{l}\text { A patient admitted for diabetes management was } \\
\text { taking amlodipine, } 5 \mathrm{mg} \text { twice daily. The treating } \\
\text { physician ordered amlodipine } 5 \mathrm{mg} \text { daily }\end{array}$ \\
\hline Incorrect dose & $\begin{array}{l}\text { A patient admitted because of a gastrointestinal } \\
\text { bleed was taking metoprolol } 12.5 \mathrm{mg} \text { twice daily } \\
\text { before admission to hospital, but the medication } \\
\text { history and medication orders indicated } \\
\text { metoprolol } 50 \mathrm{mg} \text { twice daily. }\end{array}$ \\
\hline
\end{tabular}

*Examples were obtained from a prospective study of medication discrepancies at hospital admission. medication history that were "life saving" and that $24 \%$ of the patients would have gained "significant benefit" if their omitted medications had been included. ${ }^{12}$ The third study found that $22 \%$ of the errors had the potential to cause harm if the medication was continued during the hospital stay and that $59 \%$ had the potential to cause harm if the medication was continued beyond discharge. ${ }^{16}$

Two other studies also evaluated clinical importance; however, they included errors related to drug allergy or adverse drug reaction histories in their analysis. Badowski and coauthors $^{8}$ determined that $11 \%$ of the discrepancies between pharmacist- and physician-acquired medication histories were clinically important. In the other study, 8 clinically significant discrepancies were identified among 60 patients; ${ }^{20}$ we were unable to calculate the proportion of patients who had at least 1 clinically significant discrepancy, because the patients could have had multiple discrepancies.

The prescription medications most often involved in medication history errors were cardiovascular agents (e.g., nitrates, digoxin, $\beta$-blockers), sedatives (e.g., benzodiazepines) and analgesics (e.g., NSAIDs, opioids). . $, 610,19,23,25^{2}$

\section{Interpretation}

We found that discrepancies between physicianacquired prescription medication histories and comprehensive medication histories at the time of hospital admission were common, occurring in up to $67 \%$ of cases. Published studies reported that $10 \%-61 \%$ of patients had at least 1 omission error in their prescription medications, that $13 \%-22 \%$ had at least 1 commission error and that $60 \%-67 \%$ had at least 1 omission or commission error. Five studies explicitly distinguished between unintentional discrepancies (errors) and intentional therapeutic changes through discussions with ordering physicians. These studies found that up to $54 \%$ of patients had at least 1 medication history error and that $19 \%-75 \%$ of the errors were unintentional. Limited data suggested that $11 \%-59 \%$ of the medication history errors were clinically important.

Our review reveals that prescription medication history errors at the time of hospital admission are disturbingly common and potentially harmful to patients. Our review also uncovered important considerations for future studies. First, actual medication exposure in the hospital is best reflected by admission medication orders or medication administration records, not by physician chart notes. Second, the main comparator should be a comprehensive medication history that includes an interview, inspection of medication vials or lists, or both, and contact with community pharmacies or family physicians. Comprehensive medication histories routinely obtain more information than physician-acquired histories and have been found to be highly accurate when used in patient simulations where the "actual" medication use is known. ${ }^{8,17}$ Third, there must be a distinction between intentional and unintentional discrepancies through discussion with ordering physicians. Fourth, a broad spectrum of errors, 
including those of omission, commission and dose or frequency, should be evaluated. Finally, the actual or potential clinical importance of the errors should be assessed.

Our review has several additional limitations. First, publication bias may have suppressed studies that showed low error rates. Second, our classification system for methodologic quality was arbitrary. Third, the studies in our review had a wide range of methods and results that made meta-analysis impossible. Although it is clear that prescription medication history errors are common, a precise description of the problem remains elusive. Some studies systematically overestimated errors because of the failure to distinguish between intentional and unintentional discrepancies. Other studies underestimated errors by focusing only on omission errors. Many studies excluded patients who could not provide a medication history; the error rate would likely be higher among such patients.

The results of our review indicate a need for a systematic approach to ensure the acquisition of accurate medication histories at the time of hospital admission. Physicians may benefit from additional training in obtaining complete medication histories. Such training may improve accuracy and may also help physicians recognize when a medication history is likely to be incomplete. There are many barriers to obtaining accurate medication histories, including patient illness, patient knowledge, availability of medication vials for inspection and lack of access to community pharmacy records. In addition, comprehensive medication histories take 9-30 minutes to complete, ${ }^{4,5,16-18,23,25}$ a potentially overwhelming task for busy admitting physicians. Pharmacists could be routinely involved in ensuring accurate medication histories at the time of admission, with particular attention to high-risk groups (e.g., patients with cognitive impairment using multiple medications). Patients and family members could assume a proactive role by bringing necessary medication information to the hospital and drawing attention to any deviations from the prescribed regimen. Integrated community pharmacy databases accessible to hospital staff could also enhance the accuracy of medication histories.

\section{This article has been peer reviewed.}

From the Faculty of Medicine, University of Ottawa, Ottawa, Ont. (Tam); the Faculty of Medicine, University of Western Ontario, London, Ont. (Fine); the Faculty of Pharmacy, University of Toronto, Toronto, Ont. (Marchesano); and the Department of Pharmacy (Knowles, Cornish), the Division of General Internal Medicine (Etchells) and the Patient Safety Service (Knowles, Cornish, Etchells), Sunnybrook and Women's College Health Sciences Centre, Toronto, Ont.

Competing interests: Edward Etchells has received consultation fees from the Institute for Safe Medication Practice - Canada. The other authors have declared no competing interests.

Contributors: Vincent Tam and Edward Etchells contributed significantly to the systematic review's conception and design and to the acquisition, analysis and interpretation of the data. Vincent Tam wrote the first draft of the manuscript and, along with Edward Etchells, was substantially involved in subsequent revisions. Sandra Knowles and Patricia Cornish contributed to the acquisition of the data. Nowell Fine and Romina Marchesano contributed significantly to the acquisition and analysis of the data. All of the authors provided critical revisions to the manuscript and provided final approval of the submitted manuscript.

Acknowledgements: We thank Steven Shumak and Donald Redelmeier for their helpful comments on earlier drafts of this paper. We also thank Kristine Gleason for providing us with additional detailed information regarding her study.

Vincent Tam and Romina Marchesano were supported by the Patient Safety Service, Sunnybrook and Women's College Health Sciences Centre.

\section{References}

1. Dobrzanski S, Hammond I, Khan G, Holdsworth H. The nature of hospital prescribing errors. Br 7 Clin Govern 2002;7:187-93.

2. Canadian Council on Health Services Accreditation. CCHSA patient safety goals and required organizational practices for 2005 [Communique no. 1]. Ottawa: The Council; November 2004. Available: www.cchsa.ca/pdf/PSCommunique.pdf (accessed 2005 Jul 20).

3. Joint Commission on Accreditation of Healthcare Organizations. 2005 bospitals' national patient safety goals. Oakbrook Terrace (IL): The Commission; 2005. Available: www.jcaho.org/accredited+organizations/patient+safety /05+npsg/05 npsg hap.htm (accessed 2005 Jul 20).

4. Dodds LJ. An objective assessment of the role of a pharmacist in medication and compliance history taking. Br 7 Pharm Pract 1982;12-24.

5. Cornish P, Knowles S, Marchesano R, Tam V, Shadowitz S, Juurlink D, et al. Unintended medication discrepancies at the time of hospital admission. Arch Intern Med 2005;165:424-9.

6. Hocking G, Kalyanaraman R, deMello WF. Better drug history taking: an assessment of the DRUGS mnemonic. 7 R Soc Med 1998;91:305-6.

7. Akwagyriam I, Goodyer LI, Harding L, Khakoo S, Millington H. Drug history taking and the identification of drug related problems in an accident and emergency department. 7 Accid Emerg Med 1996;13:166-8.

8. Badowski SA, Rosenbloom D, Dawson PH. Clinical importance of pharmacist-obtained medication histories using a validated questionnaire. Am 7 Hosp Pharm 1984;41:731-2.

9. Barger RC, Barger J. Pharmacist, nurse cooperate in taking drug histories. Hospitals 1976;50:93-4.

10. Beers MH, Munkata M, Storrie M. The accuracy of medication histories in hospital medical records of elderly persons. 7 Am Geriatr Soc 1990;38:1183-7.

11. Brookes K, Scott MG, McConnell JB. The benefits of a hospital based community services liason pharmacist. Pharm World Sci 2000;22:33-8.

12. Cohen J, Wilson C, Ward F. Improve drug history taking. Pharmacy in Practice 1998;1:13-6.

13. Covington TR, Pfeiffer FG. The pharmacist-acquired medication history. Am 7 Hosp Pharm 1972;29:692-5.

14. Dobbs JH. Drug histories obtained by pharmacists from psychiatric inpatients. Hosp Community Psychiatry 1981;32:639-40.

15. Drewett NM. Stop regular medicine errors. Pharmacy in Practice 1998;8:193-6.

16. Gleason KM, Groszek JM, Sullivan C, Rooney D, Barnard C, Noskin GA. Reconciliation of discrepancies in medication histories and admission orders of newly hospitalized patients. Am 7 Health Syst Pharm 2004;61:1689-95.

17. Gurwich EL. Comparison of medication histories acquired by pharmacists and physicians. Am $\mathcal{F}$ Hosp Pharm 1983;40:1541-2.

18. La Verde S. Evaluation of drug history program. Hospitals 1973;47:106-11.

19. Lau HS, Florax C, Porsius AJ, de Boer A. The completeness of medication histories in hospital medical records of patients admitted to general internal medicine wards. Br 7 Clin Pharmacol 2000;49:597-603.

20. Massey C. An evaluation of the benefits of pharmacist acquired drug histories. Proc Guild Hosp Pharm 1987;25:80-1.

21. Montpetit LM, Roy MT. Evaluation of a patient-completed versus health professional-conducted medication history. Drug Intell Clin Pharm 1988;22: 964-9.

22. Nicholls M, Horler K, Campbell D, Conroy C, Cattell R. Medicines. Peace in a POD (patients' own drug). Health Serv 7 2001;111:35.

23. Truitt CA, Longe RL, Taylor AT. An evaluation of a medication history method. Drug Intell Clin Pharm 1982;16:592-5.

24. Walchle RD, McKercher PL, Cooper JW. Physician-, nurse-, and pharmacist-conducted patient drugs histories. Contemp Pharm Pract 1980;3:75-8.

25. Wilson RS, Kabat HF. Pharmacist initiated patient drug histories. Am 7 Hosp Pharm 1971;28:49-53.

Correspondence to: Dr. Edward E. Etchells, Sunnybrook and

Women's College Health Sciences Centre, Rm. C410,

2075 Bayview Ave., Toronto ON M4N 3M5; fax 416 480-5951;

edward.etchells@sw.ca 